\title{
Impact of Urban Livestock Production on Groundwater Quality in Kaduna Metropolis, Nigeria
}

\author{
Terrumun Kenneth Kwadzah ${ }^{1}$, Oliver Terna Iorhemen ${ }^{1, *}$, Charles Amen Okuofu ${ }^{2}$ \\ ${ }^{1}$ Department of Agricultural and Environmental Engineering, University of Agriculture, Makurdi, Nigeria \\ ${ }^{2}$ Department of Water Resources and Environmental Engineering, Ahmadu Bello University, Zaria, Nigeria \\ *Corresponding author: iorhemen.terna@uam.edu.ng
}

Received July 12, 2015; Revised July 27, 2015; Accepted August 26, 2015

\begin{abstract}
Groundwater is the main source of water for most city dwellers in Nigeria. In this study, the impacts of urban livestock production on groundwater quality in Kaduna metropolis were assessed through water quality monitoring. Groundwater samples were collected from wells located around 2 abattoirs (Tudunwada and Kawo abattoirs) and in 8 livestock-keeping households for a 6-month period (July- December). Physico-chemical analyses were conducted on the samples using standard methods. Results indicate that groundwater is negatively impacted in terms of 5-day biochemical oxygen demand, chemical oxygen demand, nitrate-nitrogen, total phosphorus and cadmium; and this impact is of great concern as the values for these parameters are well in excess of established limits. There is negative impact in terms of $\mathrm{pH}$, electrical conductivity, total dissolved solids and zinc but this impact is not a concern as most of the values are within limits. However, no impact was observed on groundwater quality in terms of calcium as it showed no definite pattern of variation. Similarly, iron exhibited very low concentrations in the samples with a few exceptions in the months of July and August for the two abattoir sites. Lead was not detected in any of the samples throughout the study period. This study indicates that livestock keeping and processing activities have negative impact on groundwater quality in Kaduna metropolis. The groundwater pollution due to urban livestock production emanates from point sources and control measures can be easily applied.
\end{abstract}

Keywords: abattoir, groundwater quality, Kaduna metropolis, livestock-keeping households, urban livestock production, wells

Cite This Article: Terrumun Kenneth Kwadzah, Oliver Terna Iorhemen, and Charles Amen Okuofu, "Impact of Urban Livestock Production on Groundwater Quality in Kaduna Metropolis, Nigeria." American Journal of Water Resources, vol. 3, no. 4 (2015): 109-117. doi: 10.12691/ajwr-3-4-2.

\section{Introduction}

Urban livestock production refers to the rearing and processing of animals within municipalities (towns and cities). Examples of these animals and the products derived from them include: cattle for milk, beef and hide; goats for meat; sheep for mutton and hide; poultry for eggs and meat; and pigs for pork. In addition to providing meat and other animal-related products, urban livestock production is a source of additional income [1] for the poorly remunerated employed civil servants and traders [2] as well as retired urban dwellers. Other benefits include: employment generation for the unemployed, opportunities for organic waste recycling and uplifting of social status [3]. It also contributes to the food supply of urban households that cannot afford to purchase all their food needs. Urban livestock production further serves to balance out the animal protein demand in the city and the supply from the rural areas where there may be issues of declining production, inefficient marketing and distribution due to decaying or non-existent infrastructure especially in developing countries.

In the early part of the 20th century, many municipalities were against urban livestock production due to perceived public health risks of rearing domestic animals in close proximity to humans [4]. The concern arose from the side effects arising from urban livestock production like the pollution of soil and groundwater resulting from animal excreta and animal remains $[5,6]$ if there is no proper management in place. Additionally, if the animals are not kept on an intensive system, there may be issues of animal waste littering which may be unsightly as well as pose health hazards since livestock are known reservoirs of several zoonotic pathogens [7]. Furthermore, the waste from abattoirs, where the animals are slaughtered, pose another risk due to its high biochemical oxygen demand (BOD), nutrients and pathogens content [8,9]. Other animal-products processing industries like dairies and tanneries also have polluting effluents with attendant human and environmental health impacts.

However, due to increasing urbanization, urban livestock production is correspondingly expanding in order to feed municipal populations as well as generate household income [10] as stated earlier. In particular, the increasing demand for eggs, meat and milk is a major driving force for the expansion of urban livestock production [11]. The animals are kept under intensive systems or semi-intensive system [12] giving room for environmental-friendly management system if proper 
planning is done. In Nigeria too, the rearing of domestic animals in urban centres is a common practice.

In Kaduna metropolis, households that keep animals do so using intensive, semi-intensive or free range systems. At the abattoirs, the rumen contents of the slaughtered animals are heaped outside the abattoir and later spread on the bank of river Kaduna. This allows the liquid portion to simultaneously infiltrate into the ground and evaporate into the atmosphere. The management of the abattoir wastewater is another issue of concern.

Public water supply in Kaduna metropolis, like in most Nigerian cities, is not steady. This leads residents to resort to the abstraction of groundwater through private boreholes and hand-dug wells to supplement the public water supply. Hence, the quality of the groundwater within the metropolis is very important.

In this study, the aim was to investigate the effects of urban livestock keeping and processing activities on the groundwater quality in Kaduna metropolis through water quality monitoring.

\section{Materials and Methods}

\subsection{Description of the Study Area}

The study was conducted in Kaduna metropolis, Kaduna State, Nigeria. Kaduna metropolis lies between latitudes $10^{\circ} \mathrm{N}$ and $11^{\circ} \mathrm{N}$, and between longitudes $7^{\circ} \mathrm{E}$ and $8^{\circ} \mathrm{E}$, and at an altitude of $645 \mathrm{~m}$ above sea level [13]. Kaduna is characterized by two distinct seasons in the year: the dry season and the rainy season. The dry season runs from late October to March and is characterized by cold and dry conditions with the 'harmattan' wind that blow from north-east towards the south-west. The rainy season, which runs from April to early October, is characterised by warm and humid conditions with winds blowing from the south-west towards the north-east. The average monthly temperature for the city is between $26^{\circ} \mathrm{C}$ and $34^{\circ} \mathrm{C}$ [13].

River Kaduna passes through the middle of the metropolis. On the northern bank of the river, Tudunwada abattoir is located in Kaduna South local government area (LGA) while the Kawo abattoir is located in the Kawo area of Kaduna North LGA. The livestock-keeping households used in the study were randomly selected from Chikun, Kaduna South and Kaduna North LGAs. Figure 1 below presents a map of the study area.

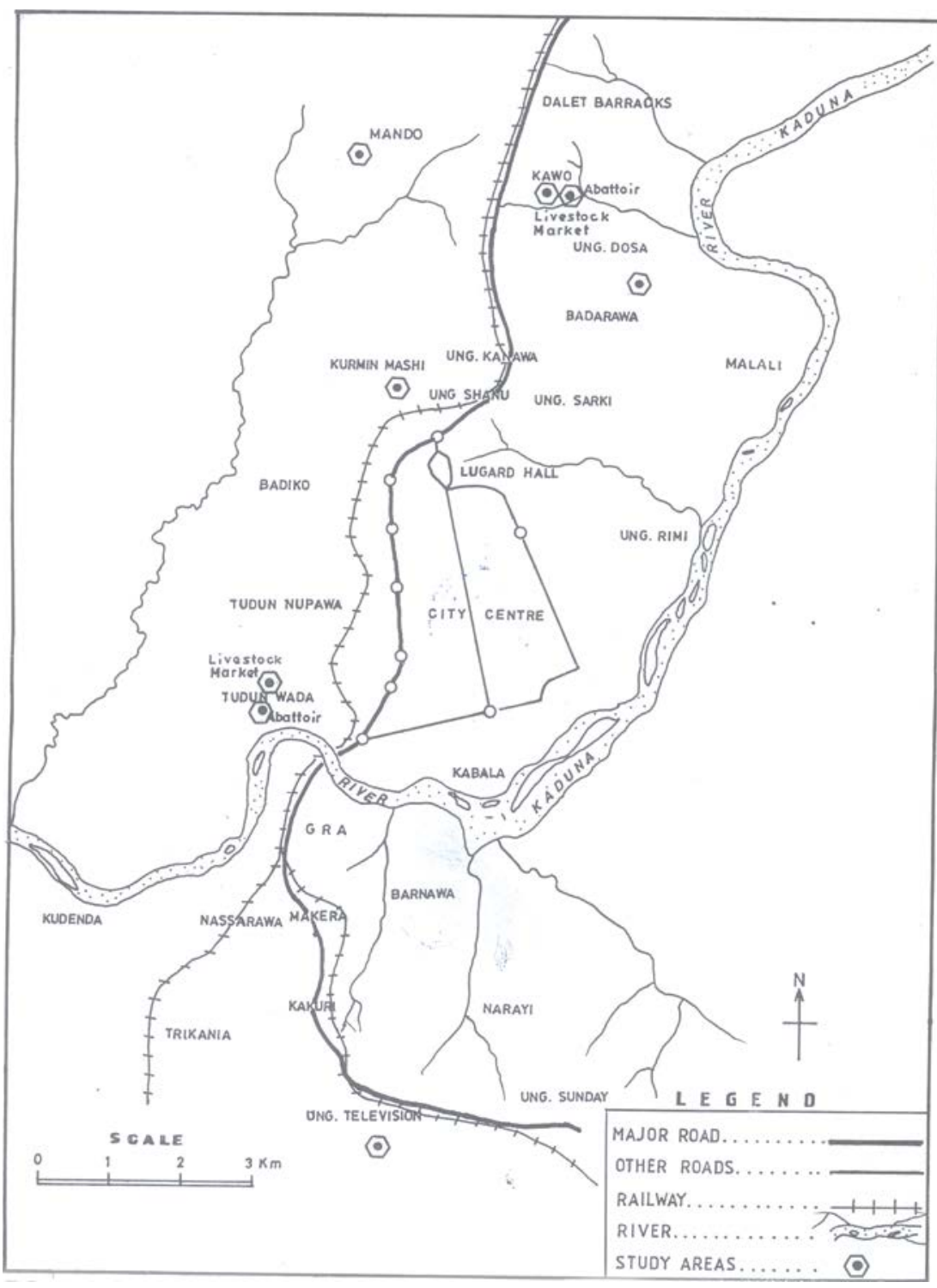

Figure 1. Map of the Study Area 


\subsection{Reconnaissance Survey}

A reconnaissance survey of the site was done to get information regarding the kinds of animals kept, the rearing system, existing waste management practices and sources of water. The survey revealed that rumen contents at the Tudunwada and Kawo abattoirs are heaped outside the abattoir and later spread on the bank of river Kaduna or directly discharged into the river. The wastewater emanating from abattoir activities in Tudunwada is conveyed to a natural channel called 'Blood River' that empties into river Kaduna. At Kawo, the abattoir wastewater is conveyed via an unlined channel into a sanitary line.

Similarly, at the livestock-keeping households (LKHs), manure is collected and heaped outside uncovered. A few farmers bag the manure and keep it under the shade for sale to crop farmers who use it for soil amendment. Unsold manure at livestock markets is disposed of at waste disposal sites used by the Kaduna State Sanitation Authority. The location of these LKHs, type of animal kept and method of animal waste management are shown in Appendix 1.

\subsection{Sampling Points}

Water samples were collected from existing wells as follows: two (2) wells at Tudunwada abattoir, two (2) wells at Kawo abattoir, and one (1) well from each of the eight (8) LKHs randomly selected from Chikun, Kaduna South and Kaduna North LGAs for the study. In addition, one well each was selected at least $100 \mathrm{~m}$ away from the Tudunwada and Kawo abattoirs to serve as control. The same thing was done for the LKHs.

\subsection{Water Sampling}

Grab water samples were collected from the selected existing wells as stated above each month, from July to December, using the buckets and ropes in regular use at the wells. The water samples were collected in 1-litre plastic bottles and taken to the laboratory for analyses. The collection of samples was done for a period of six consecutive months to capture water quality trends in the rainy season months (July to September) and dry season months (October to December). All the samples collected were transported to the laboratory and analysed within 2 hours of collection.

\subsection{Laboratory Analyses}

The following physico-chemical tests were conducted on the collected samples in the laboratory: $\mathrm{pH}$, electrical conductivity (EC), total dissolved solids (TDS), 5-day biochemical oxygen demand $\left(\mathrm{BOD}_{5}\right)$, chemical oxygen demand (COD), nitrate-nitrogen, total phosphorus, calcium, iron, zinc, lead and cadmium.

The $\mathrm{pH}$ was analyzed in-situ using Henna $\mathrm{pH}$ meter while EC and TDS were analyzed in the laboratory using standard methods. Chemical analyses were conducted in the laboratory according to the Standard Methods for the Examination of Water and Wastewater [14]. All the instruments were calibrated and standardized before using them for analyses. The determination of heavy metals was carried out by atomic absorption spectrophotometer techniques (Perkin-Elmer model 3110 equipped with HG500 graphite furnace), in flame or flameless mode, depending on element.

\section{Results and Discussion}

For ease of understanding, the meanings of the abbreviations used in the tables are presented below.

TAW Tudunwada Abattoir Wells

TACW Tudunwada Abattoir Control Well

KAW Kawo Abattoir Wells

KACW Kawo Abattoir Control Well

LKH Livestock-keeping Household

NLKH Non-livestock Keeping Household

\section{1. $\mathrm{pH}$}

The $\mathrm{pH}$ values of all the samples tested are presented in Table 1 below.

Table 1. Variation of $\mathrm{pH}$ within the Study Period

\begin{tabular}{|c|c|c|c|c|c|c|}
\hline Months & July & August & September & October & November & December \\
\hline TAW Range & $6.09-6.60$ & $6.32-6.59$ & $6.52-7.51$ & $6.74-6.95$ & $6.61-7.02$ & $6.27-7.89$ \\
\hline TAW Mean & $6.35 \pm 0.36$ & $6.46 \pm 0.19$ & $7.02 \pm 0.7$ & $6.85 \pm 0.15$ & $6.82 \pm 0.29$ & $7.08 \pm 1.15$ \\
\hline TACW & 6.82 & 6.9 & 5.81 & 6.78 & 6.9 & 6.8 \\
\hline KAW Range & $6.42-6.70$ & $6.17-6.48$ & $6.07-6.38$ & $6.32-6.38$ & $6.52-6.90$ & $6.89-7.65$ \\
\hline KAW Mean & $6.56 \pm 0.20$ & $6.33 \pm 0.22$ & $6.23 \pm 0.22$ & $6.35 \pm 0.22$ & $6.71 \pm 0.27$ & $7.27 \pm 0.53$ \\
\hline KACW & 6.81 & 6.72 & 6.67 & 6.48 & 6.72 & 6.75 \\
\hline LKH Range & $6.34-6.78$ & $6.04-7.00$ & $6.39-6.92$ & $6.23-8.01$ & $6.45-7.61$ & $6.81-7.27$ \\
\hline LKH Mean & $6.56 \pm 0.25$ & $6.52 \pm 0.31$ & $6.66 \pm 0.18$ & $7.12 \pm 0.73$ & $7.03 \pm 0.41$ & $7.04 \pm 0.17$ \\
\hline NLKH & 6.8 & 6.95 & 6.85 & 6.84 & 6.92 & 7.27 \\
\hline
\end{tabular}

The $\mathrm{pH}$ of a water sample is particularly important if the water is to undergo some form of chemical treatment e.g. coagulation/flocculation, disinfection, etc. The average $\mathrm{pH}$ values for samples from the Tudunwada abattoir wells were in excess of the control well from September to December. Most of the $\mathrm{pH}$ values fall within the range recommended by both the World Health Organisation (WHO) and Nigerian Standards for Drinking
Water Quality (NSDWQ) which is 6.5 - 8.5 [15,16]. This implies that although there is impact on groundwater in terms of $\mathrm{pH}$, this impact is not of a concern.

\subsection{Electrical Conductivity}

The EC values of all the samples tested are presented in Table 2 below. 
Table 2. Variation of Electrical Conductivity $(\mu \mathrm{S} / \mathrm{cm})$

\begin{tabular}{|c|c|c|c|c|c|c|}
\hline Months & July & August & September & October & November & December \\
\hline TAW Range & $1100-3900$ & $1100-3900$ & $1600-1760$ & $1300-1680$ & $2200-2600$ & $1235-1320$ \\
\hline TAW Mean & $2500 \pm 1800$ & $2500 \pm 1980$ & $1680 \pm 113$ & $1490 \pm 268$ & $2400 \pm 283$ & $1278 \pm 60$ \\
\hline TACW & 120 & 180 & 510 & 310 & 120 & 125 \\
\hline KAW Range & $510-900$ & $480-3700$ & $790-1500$ & $620-970$ & $212-635$ & $190-210$ \\
\hline KAW Mean & $705 \pm 276$ & $2090 \pm 2277$ & $1145 \pm 502$ & $795 \pm 247$ & $424 \pm 299$ & $200 \pm 14$ \\
\hline KACW & 300 & 420 & 420 & 340 & 135 & 125 \\
\hline LKH Range & $115-850$ & $120-1000$ & $470-1670$ & $125-990$ & $117-1640$ & $106-960$ \\
\hline LKH Mean & $495 \pm 201$ & $479 \pm 338$ & $960 \pm 393$ & $594 \pm 317$ & $563 \pm 495$ & $434 \pm 301$ \\
\hline NLKH & 209 & 150 & 371 & 201 & 312 & 213 \\
\hline
\end{tabular}

EC values for all samples were above their groundwater quality in terms of EC. For the LKHs, corresponding control values throughout the study period. Most of the values for the two abattoirs were in excess of the maximum value recommended for drinking water by NSDWQ - $1300 \mu \mathrm{S} / \mathrm{cm}$ [16]. For the livestock keeping households, all the average values were within the limits throughout the study period. This clearly indicates that livestock keeping and processing has affected the although there is impact on the groundwater quality, all the values are within established safe limits.

\subsection{Total Dissolved Solids}

TDS values of all the samples tested are presented in Table 3.

Table 3. Variation of Total Dissolved Solids (mg/L)

\begin{tabular}{|c|c|c|c|c|c|c|}
\hline Months & July & August & September & October & November & December \\
\hline TAW Range & $300-720$ & $400-650$ & $401-1600$ & $471-1030$ & $150-180$ & $140-175$ \\
\hline TAW Mean & $510 \pm 297$ & $525 \pm 177$ & $1001 \pm 848$ & $750 \pm 396$ & $165 \pm 21$ & $158 \pm 25$ \\
\hline TACW & 120 & 250 & 142 & 35 & 50 & 126 \\
\hline KAW Range & $200-753$ & $100-200$ & $602-700$ & $690-754$ & $147-165$ & $145-168$ \\
\hline KAW Mean & $477 \pm 391$ & $150 \pm 71$ & $651 \pm 69$ & $722 \pm 45$ & $156 \pm 13$ & $157 \pm 16$ \\
\hline KACW & 210 & 140 & 450 & 546 & 139 & 86 \\
\hline LKH Range & $80-148$ & $90-160$ & $87-160$ & $85-280$ & $35-350$ & $31-202$ \\
\hline LKH Mean & $107 \pm 8$ & $119 \pm 27$ & $117 \pm 25$ & $152 \pm 60$ & $134 \pm 118$ & $98 \pm 72$ \\
\hline NLKH & 105 & 110 & 126 & 121 & & 57 \\
\hline
\end{tabular}

The NSDWQ maximum permitted value for TDS in values obtained for the abattoir wells and LKHs were all drinking water is $500 \mathrm{mg} / \mathrm{L}$ [16]. WHO on the other hand, states that drinking water becomes greatly and progressively unpalatable at TDS concentrations above $1000 \mathrm{mg} / \mathrm{L}$ [15]. The abattoir wells had TDS values above the NSDWQ limit of $500 \mathrm{mg} / \mathrm{L}$ from July to October. This corresponds to the rainy season when the animal waste would have been dissolved by the water that infiltrated and percolated into the soil. The LKHs had TDS below above their corresponding controls, indicating an impact of livestock keeping and processing on groundwater quality.

\subsection{Biochemical Oxygen Demand}

The results obtained for $\mathrm{BOD}_{5}(\mathrm{mg} / \mathrm{L})$ are presented in Table 4 below.

Table 4. Variation of 5-day Biochemical Oxygen Demand (mg/L)

\begin{tabular}{|c|c|c|c|c|c|c|}
\hline Months & July & August & September & October & November & December \\
\hline TAW Range & $60-80$ & $80-150$ & $100-180$ & $70-70$ & $20-190$ & $20-60$ \\
\hline TAW Mean & $70 \pm 14$ & $115 \pm 49$ & $140 \pm 57$ & $70 \pm 0$ & $105 \pm 120$ & $40 \pm 28$ \\
\hline TACW & 50 & 50 & 50 & 20 & 7 & 20 \\
\hline KAW Range & $80-90$ & $80-170$ & $30-60$ & $60-60$ & $40-50$ & $30-50$ \\
\hline KAW Mean & $85 \pm 7$ & $125 \pm 64$ & $45 \pm 21$ & $60 \pm 0$ & $45 \pm 7$ & $40 \pm 14$ \\
\hline KACW & 20 & 90 & 38 & 30 & 60 & 20 \\
\hline LKH Range & $8-16$ & $7-170$ & $5-13$ & $4-19$ & $20-60$ & $10-30$ \\
\hline LKH Mean & $11 \pm 4$ & $39 \pm 54$ & $10 \pm 3$ & $8 \pm 5$ & $30 \pm 16$ & $25 \pm 8$ \\
\hline NLKH & 5 & 6 & 7 & 3 & 4 & 20 \\
\hline
\end{tabular}

Most of the $\mathrm{BOD}_{5}$ values are above $20 \mathrm{mg} / \mathrm{L}$, the discharge consent for treated wastewater [17]. However, this value is too high for drinking water. All the values obtained for the abattoir wells and LKHs were all above their corresponding controls, indicating an impact on groundwater quality, though very small. 


\subsection{Chemical Oxygen Demand}

Table 5 below presents the results obtained for COD (mg/L) throughout the study period.

Table 5. Variation of Chemical Oxygen Demand (mg/L)

\begin{tabular}{|c|c|c|c|c|c|c|}
\hline Months & July & August & September & October & November & December \\
\hline TAW Range & $304-336$ & $184-240$ & $350-380$ & $370-490$ & $310-420$ & $160-170$ \\
\hline TAW Mean & $320 \pm 23$ & $212 \pm 40$ & $365 \pm 21$ & $430 \pm 85$ & $365 \pm 78$ & $165 \pm 7$ \\
\hline TACW & 201 & 160 & 95 & 262 & 250 & 68 \\
\hline KAW Range & $264-312$ & $280-320$ & $180-210$ & $180-360$ & $169-200$ & $121-125$ \\
\hline KAW Mean & $288 \pm 34$ & $300 \pm 28$ & $195 \pm 21$ & $270 \pm 127$ & $185 \pm 22$ & $123 \pm 3$ \\
\hline KACW & 156 & 160 & 170 & 270 & 68 & 47 \\
\hline LKH Range & $152-213$ & $161-270$ & $150-270$ & $141-214$ & $62-188$ & $31-131$ \\
\hline LKH Mean & $167 \pm 27$ & $214 \pm 46$ & $206 \pm 42$ & $187 \pm 22$ & $124 \pm 44$ & $71 \pm 33$ \\
\hline NLKH & 96 & 102 & 106 & 97 & 66 & 41 \\
\hline
\end{tabular}

The COD values are higher in magnitude than their corresponding $\mathrm{BOD}_{5}$ counterpart in section 3.4 above. This is because COD is a measure of wastes which are both biodegradable and non biodegradable, hence covering a broader spectrum [18]. COD showed a similar pattern of variation as $\mathrm{BOD}_{5}$. As with $\mathrm{BOD}_{5}$, all the values obtained for the abattoir wells and LKHs were all above their corresponding controls.

\subsection{Nitrate - nitrogen}

The results obtained for nitrate - nitrogen in $\mathrm{mg} / \mathrm{L}$ are presented in Table 6 below.

Table 6. Nitrate-nitrogen Variation $(\mathrm{mg} / \mathrm{L})$

\begin{tabular}{|c|c|c|c|c|c|c|}
\hline Months & July & August & September & October & November & December \\
\hline TAW Range & $40-51$ & $54-72$ & $64-85$ & $53-53$ & $77-80$ & $54-56$ \\
\hline TAW Mean & $46 \pm 8$ & $63 \pm 13$ & $75 \pm 15$ & $53 \pm 0$ & $79 \pm 2$ & $55 \pm 1$ \\
\hline TACW & 15 & 13 & 26 & 16 & 12 & 12 \\
\hline KAW Range & $36-40$ & $42-50$ & $52-69$ & $43-44$ & $29-31$ & $37-41$ \\
\hline KAW Mean & $38 \pm 3$ & $46 \pm 6$ & $61 \pm 12$ & $44 \pm 1$ & $30 \pm 1$ & $39 \pm 3$ \\
\hline KACW & 30 & 26 & 20 & 18 & 11 & 11 \\
\hline LKH Range & $15-38$ & $13-46$ & $13-52$ & $14-42$ & $10-26$ & $10-89$ \\
\hline LKH Mean & $20 \pm 7$ & $24 \pm 11$ & $30 \pm 13$ & $28 \pm 9$ & $16 \pm 6$ & $35 \pm 24$ \\
\hline NLKH & 12 & 12 & 12 & 15 & 12 & 12 \\
\hline
\end{tabular}

In order to protect bottle-fed infants against methaemoglobinaemia (blue-baby syndrome), WHO recommends $50 \mathrm{mg} / \mathrm{L}$ limit as nitrate ion or $11 \mathrm{mg} / \mathrm{L}$ as nitrate-nitrogen [15]. The NSDWQ on the other hand, stipulates a maximum permitted nitrate concentration of $50 \mathrm{mg} / \mathrm{L}$ in drinking water [16]. The nitrate-N levels in the abattoir wells and LKHs samples were all above their corresponding controls, indicating that livestock rearing and processing has effects on the groundwater quality. The high levels of nitrate - nitrogen are attributable to the interaction between livestock wastes in the vicinity of the wells and well water occasioned by unhygienic anthropogenic activities at the sites. In addition, the nitrate- $\mathrm{N}$ in the faeces and urine of animals around the sites moves with the infiltrating water through the soil into wells [19].

\subsection{Total Phosphorus}

Table 7 below presents the results obtained for total phosphorus (mg/L) throughout the study period.

Table 7. Variation of Total Phosphorus (mg/L)

\begin{tabular}{|c|c|c|c|c|c|c|}
\hline Months & July & August & September & October & November & December \\
\hline TAW Range & $1.0-1.1$ & $0.9-1.4$ & $4.6-5.8$ & $4.8-13.2$ & $5.0-22.9$ & $1.3-1.5$ \\
\hline TAW Mean & $1.1 \pm 0.1$ & $1.2 \pm 0.4$ & $5.2 \pm 0.8$ & $9.0 \pm 5.9$ & $14.0 \pm 12.7$ & $1.4 \pm 0.1$ \\
\hline TACW & 0 & 0 & 5.4 & 7.0 & 4.4 & 1.1 \\
\hline KAW Range & $1.0-1.1$ & $1.0-1.0$ & $5.0-5.8$ & $5.1-9.2$ & $4.2-4.6$ & $1.0-1.2$ \\
\hline KAW Mean & $1.1 \pm 0.1$ & $1.0 \pm 0$ & $5.4 \pm 0.6$ & $7.2 \pm 2.9$ & $4.4 \pm 0.3$ & $1.1 \pm 0.1$ \\
\hline KACW & 1.0 & 1.0 & 4.2 & 4.0 & 1.0 & 0.9 \\
\hline LKH Range & $0.4-4.8$ & $0.9-5.1$ & $1.0-9.2$ & $1.0-8.1$ & $0.0-8.2$ & $0.0-4.9$ \\
\hline LKH Mean & $2.4 \pm 1.0$ & $1.6 \pm 1.5$ & $4.7 \pm 2.7$ & $3.5 \pm 2.4$ & $2.9 \pm 2.7$ & $1.9 \pm 1.8$ \\
\hline NLKH & 1.0 & 0 & 1.0 & 0.9 & 0.5 & 1.0 \\
\hline
\end{tabular}


Phosphorus is very essential for animals. It is required for normal soft and skeletal tissue (e.g. bones and teeth) development [20]. Hence animal waste and other organic wastes have relatively high levels of phosphorus $[21,22,23]$. A significant portion of the total phosphorus in soil solution is present as dissolved organic phosphorus [24]. The dissolved organic phosphorus infiltrates and percolates with soil water. One of the undesirable effects of phosphorus' presence in water is depletion of dissolved oxygen. In surface waters, other negative effects may include: eutrophication and death of aquatic animals. Total phosphorus levels were very low for all the samples. These concentrations were however, equal or above their corresponding controls, pointing to the contribution of animal wastes to the relatively higher levels of in abattoir and LKH samples.

\subsection{Calcium}

The results obtained for calcium in $\mathrm{mg} / \mathrm{L}$ are presented in Table 8 below.

Table 8. Variation of Calcium (mg/L)

\begin{tabular}{|c|c|c|c|c|c|c|}
\hline Months & July & August & September & October & November & December \\
\hline TAW Range & $14-30$ & $18-32$ & $17-44$ & $20-65$ & $30-51$ & $40-54$ \\
\hline TAW Mean & $22 \pm 11$ & $25 \pm 10$ & $31 \pm 19$ & $43 \pm 32$ & $41 \pm 15$ & $47 \pm 10$ \\
\hline TACW & 20 & 20 & 25 & 50 & 40 & 20 \\
\hline KAW Range & $17-36$ & $25-82$ & $16-16$ & $48-51$ & $63-82$ & $15-18$ \\
\hline KAW Mean & $27 \pm 13$ & $54 \pm 40$ & $16 \pm 0$ & $50 \pm 2$ & $43 \pm 13$ & 29 \\
\hline KACW & 30 & 35 & 30 & 76 & $5-17$ & $2-13$ \\
\hline LKH Range & $2-9$ & $3-8$ & $5-10$ & $11.5 \pm 3.2$ & $10.1 \pm 3.8$ & $5.8 \pm 3.6$ \\
\hline LKH Mean & $3.8 \pm 2$ & $4.6 \pm 1.6$ & $6.7 \pm 1.7$ & 8.5 & 9.0 & 4.9 \\
\hline NLKH & 2.5 & 3.8 & 5.1 & & & 29 \\
\hline
\end{tabular}

The presence of calcium in water is not known to cause physiological effects to humans [25], hence both NSDWQ and WHO have no limit for it in drinking water. However, calcium and magnesium are responsible for water hardness which leads to more soap consumption during laundry. Calcium showed no definite pattern of variation. Some control values were more than the tested samples.

This shows that livestock activities around the sites had no direct influence on the calcium concentration.

\subsection{Iron}

The results obtained for iron in $\mathrm{mg} / \mathrm{L}$ are presented in Table 9 below.

Table 9. Variation of Calcium (mg/L)

\begin{tabular}{|c|c|c|c|c|c|c|}
\hline Months & July & August & September & October & November & December \\
\hline TAW Range & $0-28.9$ & $0-14.5$ & $0.1-0.3$ & 0 & $0.1-0.7$ & $0.2-0.3$ \\
\hline TAW Mean & $14.5 \pm 20$ & $7.3 \pm 10$ & $0.2 \pm 0.1$ & 0 & $0.4 \pm 0.4$ & $0.3 \pm 0.1$ \\
\hline TACW & 0 & 0 & 0.1 & 0 & 0 & 0 \\
\hline KAW Range & $0-7.2$ & $6.8-7.2$ & $0.1-0.1$ & $0-0.3$ & $0-0.1$ & 0 \\
\hline KAW Mean & $3.6 \pm 5.1$ & $7.0 \pm 0.3$ & $0.1 \pm 0$ & $0.2 \pm 0.2$ & $0.1 \pm 0.1$ & 0 \\
\hline KACW & 1.0 & 0 & 0 & 0 & 0 & 0 \\
\hline LKH Range & 0 & 0 & $0.1-0.3$ & 0 & 0 & 0 \\
\hline LKH Mean & 0 & 0 & $0.2 \pm 0.1$ & 0 & 0 & 0 \\
\hline NLKH & 0 & 0 & 0.2 & 0 & 0 \\
\hline
\end{tabular}

Iron is an essential macro nutrient for the normal functioning of all living organisms, hence animal wastes would contain iron. Though iron is beneficial in human diet at low concentrations [26], elevated concentrations produce objectionable reddish-brown colour in the water due to the oxidation of ferrous iron to ferric iron. The concentrations of iron in the samples were generally low with a few exceptions in the months of July and August for the two abattoir sites. The reason for this high values in those months could be as a result of pieces of iron that may have come in contact with the water since the wells had no cover, or dust and other extraneous materials may have found their way into the wells. Generally, the concentration of iron in natural fresh waters ranges from 0.5 to $50 \mathrm{mg} / \mathrm{L}$ [15]. NSDWQ recommended limit in drinking water is $0.3 \mathrm{mg} / \mathrm{L} \mathrm{[16]}$. This is because iron concentrations above $0.3 \mathrm{mg} / \mathrm{L}$ cause staining of laundry and plumbing fixtures [15]. Most samples met this standard during the study period.

\subsection{Zinc}

The results obtained for zinc in $\mathrm{mg} / \mathrm{L}$ are presented in Table 10 below.

Zinc is an essential trace element found in almost all food; hence its source is diet. Drinking-water become unacceptable to customers at zinc concentrations above 3 $\mathrm{mg} / \mathrm{L}$ [15]. Based on this, NSDWQ set a maximum threshold of $3 \mathrm{mg} / \mathrm{L}$ in drinking water [16]. None of the samples exceeded this value during the period of the study. However, all the samples were above their respective controls indicating an impact of livestock activities on groundwater quality. This impact, however, is of no concern. 
Table 10. Zinc Variation (mg/L)

\begin{tabular}{|c|c|c|c|c|c|c|}
\hline Months & July & August & September & October & November & December \\
\hline TAW Range & $0.16-0.23$ & $0.16-0.36$ & $0.36-0.43$ & $0.36-0.51$ & $0.14-0.25$ & 0 \\
\hline TAW Mean & $0.20 \pm 0.05$ & $0.26 \pm 0.14$ & $0.40 \pm 0.05$ & $0.44 \pm 0.11$ & $0.20 \pm 0.08$ & 0 \\
\hline TACW & 0.12 & 0.07 & 0.07 & 0.08 & 0.02 & 0 \\
\hline KAW Range & $0.31-0.63$ & $0.39-0.47$ & $0.18-0.29$ & $0.18-0.67$ & $0.12-0.26$ & 0 \\
\hline KAW Mean & $0.47 \pm 0.23$ & $0.43 \pm 0.06$ & $0.24 \pm 0.08$ & $0.43 \pm 0.35$ & $0.19 \pm 0.10$ & 0 \\
\hline KACW & 0.06 & 0.63 & 0.62 & 0.4 & 0.04 & 0.21 \\
\hline LKH Range & 0 & $0-0.50$ & $0-0.61$ & $0-0.39$ & $0-0.27$ & $0-0.21$ \\
\hline LKH Mean & 0 & $0.22 \pm 0.21$ & $0.32 \pm 0.23$ & $0.21 \pm 0.14$ & $0.15 \pm 0.10$ & $0.03 \pm 0.07$ \\
\hline NLKH & 0 & 0 & 0 & 0 & 0 & 0 \\
\hline
\end{tabular}

\subsection{Lead}

Lead was not detected in any of the samples throughout the study period.

\subsection{Cadmium}

The results obtained for cadmium in $\mathrm{mg} / \mathrm{L}$ are presented in Table 11 below.

Table 11. Variation of Cadmium (mg/L)

\begin{tabular}{|c|c|c|c|c|c|c|}
\hline Months & July & August & September & October & November & December \\
\hline TAW Range & 0 & 0 & $0.06-0.09$ & $0.03-0.06$ & $0.06-0.06$ & $0.05-0.05$ \\
\hline TAW Mean & 0 & 0 & $0.08 \pm 0.02$ & $0.05 \pm 0.02$ & $0.06 \pm 0$ & $0.05 \pm 0$ \\
\hline TACW & 0 & 0 & 0 & 0 & 0 & 0.05 \\
\hline KAW Range & 0 & 0 & $0.03-0.09$ & $0.03-0.06$ & $0.03-0.06$ & $0.01-0.05$ \\
\hline KAW Mean & 0 & 0 & $0.06 \pm 0.04$ & $0.05 \pm 0.02$ & $0.05 \pm 0.02$ & $0.03 \pm 0.03$ \\
\hline KACW & 0 & 0 & 0.03 & 0 & 0 & 0 \\
\hline LKH Range & 0 & 0 & $0-0.03$ & $0-0.03$ & $0-0.03$ & $0-0.90$ \\
\hline LKH Mean & 0 & 0 & $0.01 \pm 0.01$ & $0.01 \pm 0.01$ & $0 \pm 0.01$ & $0.11 \pm 0.32$ \\
\hline NLKH & 0 & 0 & 0.03 & 0 & 0 & 0 \\
\hline
\end{tabular}

Cadmium is a major health concern because it is known to cause lung, prostate and renal cancers [27]. Another big concern is cadmium's long half-life and persistence in the environment and in tissues [28]. In view of this, the guideline value of $0.003 \mathrm{mg} / \mathrm{L}$ has been set in both NSDWQ and WHO guidelines for drinking-water [15,16]. Cadmium was not detected in any of the samples in July and August but appeared in most sites from September to December. When it appeared, the detected levels were all above the NSDWQ and WHO maximum allowable concentration in drinking water. In the control samples, it was detected only in December at the Tudunwada abattoir, in September at Kawo abattoir and LKHs. However, the concentrations of cadmium in all the controls, when it appeared, were above the threshold. Also, the concentrations of the heavy metal in all the samples from September to October were above their corresponding controls. This indicates an impact of livestock wastes on groundwater; although the fact that the concentration of cadmium in the control samples were also above the threshold indicates that the presence of cadmium in groundwater may have also been contributed by natural sources.

\section{Conclusion}

Urban livestock production, in addition to providing meat and animal-related products, serves as additional income for low income earners, traders and retirees. It however, poses some environmental pollution threats. This research assessed the impact of livestock keeping and processing activities on groundwater quality in Kaduna metropolis through water quality monitoring from July to December.

Findings indicate that urban livestock production has negatively impacted groundwater in terms of $\mathrm{pH}$, EC, TDS, and zinc but this impact is not a concern as most of the values are within NSDWQ and WHO guideline values. In terms of $\mathrm{BOD}_{5}, \mathrm{COD}$, nitrate- $\mathrm{N}$, total phosphorus and cadmium, the levels detected show negative impact on groundwater of great concern. Cadmium's presence (concentrations well above NSDWQ and WHO limits) is also attributable to natural sources. However, urban livestock production showed no effect on groundwater in terms of calcium, iron and lead.

This research has shown that groundwater pollution caused by livestock wastes emanates from point sources: abattoirs and livestock-keeping households. This implies control measures can be easily applied at the source. The water quality data and pollution source information obtained from this research will be useful in identifying water quality problem areas and planning of engineering interventions.

\section{Acknowledgement}

The authors wish to acknowledge the immense contributions of the technicians and technologists at the 
Public Health Engineering Laboratory, Department of Water Resources and Environmental Engineering, Ahmadu Bello University, Zaria - Nigeria.

\section{Statement of Competing Interests}

The authors have no competing interests.

\section{List of Abbreviations}

$\begin{array}{ll}\text { BOD } & \text { Biochemical Oxygen Demand } \\ \text { BOD }_{5} & \text { 5-day Biochemical Oxygen Demand } \\ \text { COD } & \text { Chemical Oxygen Demand } \\ \text { DO } & \text { Dissolved Oxygen } \\ \text { EC } & \text { Electrical Conductivity } \\ \text { KACW } & \text { Kawo Abattoir Control Well } \\ \text { KAW } & \text { Kawo Abattoir Wells } \\ \text { LGA } & \text { Local Government Area } \\ \text { LKH } & \text { Livestock Keeping Household } \\ \text { NLKH } & \text { Non-livestock Keeping Household } \\ \text { NSDWQ } & \text { Nigerian Standards for Drinking Water } \\ & \text { Quality } \\ \text { TACW } & \text { Tudunwada Abattoir Control Well } \\ \text { TAW } & \text { Tudunwada Abattoir Wells } \\ \text { TDS } & \text { Total Dissolved Solids } \\ \text { TSS } & \text { Total Suspended Solids } \\ \text { WHO } & \text { World Health Organisation }\end{array}$

\section{References}

[1] Lupindu, A.M., Ngowi, H.A., A., D., Olsen, J.E., and Msoffe, P.L.M., (2012). Current manure management practices and hygiene aspects of urban and peri-urban livestock farming in Tanzania. Livestock Research for Rural Development, 2012. 24(9).

[2] Muhammad, I.R., (2008). Livestock Ownership and Unconventional Feed Resources from Refuse Dumps in Urban Metropolis of Semi Arid Zone. Research Journal of Animal Sciences, 2008. 2(1): p. 12-16.

[3] Gillah, K.A., Kifaro, G.C., and Madsen, J., (2012). Urban and peri urban dairy farming in East Africa: A review on production levels, constraints and opportunities. Livestock Research for Rural Development, 2012. 24(11): p. 198.

[4] McClintock, N., Pallana, E., and Wooten, H., (2014). Urban livestock ownership, management, and regulation in the United States: An exploratory survey and research agenda. Land Use Policy, 2014. 38: p. 426-440.

[5] Thys, E., Oueadraogo, M., Speybroeck, N., and Geerts, S., (2005). Socio-economic determinants of urban household livestock keeping in semi-arid Western Africa. Journal of Arid Environments, 2005. 63(2): p. 475-496.

[6] Mouri, G. and Aisaki, N., (2015). Using land-use management policies to reduce the environmental impacts of livestock farming. Ecological Complexity, 2015. 22: p. 169-177.

[7] Heuvelink, A.E., Valkenburgh, S.M., Tilburg, J.J.H.C., Van Heerwaarden, C., Zwartkruis-Nahuis, J.T.M., and De Boer, E., (2007). Public farms: hygiene and zoonotic agents. Epidemiology \& Infection, 2007. 135(07): p. 1174-1183.
[8] Keskes, S., Hmaied, F., Gannoun, H., Bouallagui, H., Godon, J.J., and Hamdi, M., (2012). Performance of a submerged membrane bioreactor for the aerobic treatment of abattoir wastewater. Bioresource Technology, 2012. 103(1): p. 28-34.

[9] Matsumura, E.M. and Mierzwa, J.C., (2008). Water conservation and reuse in poultry processing plant-A case study. Resources, Conservation and Recycling, 2008. 52(6): p. 835-842.

[10] Mlozi, M.S., (1997). Impacts of urban agriculture in Dar es Salaam, Tanzania. Environmentalist, 1997. 17(2): p. 115-124.

[11] Udo, H.M.J., Aklilu, H.A., Phong, L.T., Bosma, R.H., Budisatria, I.G.S., Patil, B.R., Samdup, T., and Bebe, B.O., (2011). Impact of intensification of different types of livestock production in smallholder crop-livestock systems. Livestock Science, 2011. 139(1-2): p. 22-29.

[12] Lupindu, A.M., Dalsgaard, A., Msoffe, P.L.M., Ngowi, H.A., Mtambo, M.M., and Olsen, J.E., (2015). Transmission of antibiotic-resistant Escherichia coli between cattle, humans and the environment in peri-urban livestock keeping communities in Morogoro, Tanzania. Preventive Veterinary Medicine, 2015. 118(4): p. 477-482.

[13] Bununu, Y.A., Ludin, A.N.M., and Hosni, N., (2015). City profile: Kaduna. Cities, 2015. 49: p. 53-65.

[14] APHA, (1998). Standard methods for the examination of water and wastewater, 20th edition. Washington: American Public Health Association (APHA).

[15] WHO, (2011). Guidelines for Drinking-water Quality, 4th ed. Geneva: World Health Organization.

[16] NSDWQ, (2007). Nigerian Standard for Drinking Water Quality. Nigerian Industrial Standard NIS 554. Lagos, Nigeria: Standard Organization of Nigeria.

[17] Tebbutt, T.H.Y., (1998).Principles of water quality control. Boston, MA: ButterWorth-Heinemann.

[18] Han, D., Concise Environmental Engineering 1st edn. 2011.

[19] Hubbard, R.K., Newton, G.L., and Hill, G.M., (2004). Water quality and the grazing animal. Journal of Animal Science, 2004. 82(13_suppl): p. E255-E263.

[20] Esser, N.M., Hoffman, P.C., Coblentz, W.K., Orth, M.W., and Weigel, K.A., (2009). The effect of dietary phosphorus on bone development in dairy heifers. Journal of Dairy Science, 2009. 92(4): p. 1741-1749.

[21] Schumann, A. and Sumner, M., (2004). Formulation of Environmentally Sound Waste Mixtures for Land Application. Water, Air, and Soil Pollution, 2004. 152(1-4): p. 195-217.

[22] Wang, F., Sims, J.T., Ma, L., Ma, W., Dou, Z., and Zhang, F., (2011). The Phosphorus Footprint of China's Food Chain: Implications for Food Security, Natural Resource Management, and Environmental Quality. Journal of Environmental Quality, 2011. 40(4): p. 1081-1089.

[23] Li, G., Li, H., Leffelaar, P.A., Shen, J., and Zhang, F., (2014). Characterization of phosphorus in animal manures collected from three (dairy, swine, and broiler) farms in China. PLoS ONE, 2014. 9(7): p. e102698.

[24] Chardon, W.J., Oenema, O., del Castilho, P., Vriesema, R., Japenga, J., and Blaauw, D., (1997). Organic Phosphorus in Solutions and Leachates from Soils Treated with Animal Slurries. Journal of Environmental Quality, 1997. 26(2): p. 372-378.

[25] Alley, E.R., Water Quality Control Handbook, 2nd ed. 2007, McGraw-Hill ; WEF Press: New York; Alexandria.

[26] Twort, A.C., Ratnayaka, D.D., and Brandt, M.J., (2002).Water Supply. 5th ed. Oxford: Butterworth-Heinamann; copublished by IWA Publishing.

[27] Waalkes, M.P., (2003). Cadmium carcinogenesis. Mutation Research/Fundamental and Molecular Mechanisms of Mutagenesis, 2003. 533(1-2): p. 107-120.

[28] Joseph, P., (2009). Mechanisms of cadmium carcinogenesis. Toxicology and Applied Pharmacology, 2009. 238(3): p. 272-279. 
Appendix 1: Location of livestock keeping households, types animal reared, and existing method of animal waste management

\begin{tabular}{|c|c|c|c|c|c|}
\hline Designation & Location & Use of the Well & $\begin{array}{l}\text { Types of animals } \\
\text { kept }\end{array}$ & Type of husbandry & Waste Management System \\
\hline LKH1 & $\begin{array}{l}\text { Chiroma street in Chikun } \\
\text { LGA }\end{array}$ & $\begin{array}{l}\text { basic source of water } \\
\text { for both human and } \\
\text { animal consumption }\end{array}$ & $\begin{array}{l}\text { Goats, pigs and } \\
\text { poultry }\end{array}$ & $\begin{array}{l}\text { Kept in separate } \\
\text { confined housing } \\
\text { systems }\end{array}$ & $\begin{array}{l}\text { Animal manure is collected } \\
\text { and kept in bags for sale to } \\
\text { arable crop farmers. Unsold } \\
\text { manure is disposed of at a } \\
\text { nearby waste dump site. }\end{array}$ \\
\hline LKH2 & $\begin{array}{l}\text { Iyaka street, Angwan mai } \\
\text { Chibi, Television, Chikun } \\
\text { LGA }\end{array}$ & $\begin{array}{l}\text { Supplementary source } \\
\text { of water for both } \\
\text { human and animal } \\
\text { consumption } \\
\end{array}$ & $\begin{array}{l}\text { Goats, sheep and } \\
\text { poultry }\end{array}$ & $\begin{array}{l}\text { Goats and sheep in a } \\
\text { confined system; local } \\
\text { chickens on a free- } \\
\text { range system } \\
\end{array}$ & $\begin{array}{l}\text { Animal excreta (dung) are } \\
\text { swept regularly together with } \\
\text { feed remnants and dumped at a } \\
\text { nearby waste disposal heap. }\end{array}$ \\
\hline LKH3 & $\begin{array}{l}\text { Kaduna polytechnic } \\
\text { Quarters along Kachia } \\
\text { Road, Kaduna South LGA }\end{array}$ & $\begin{array}{l}\text { Supplementary source } \\
\text { of water for animal } \\
\text { feeding only }\end{array}$ & Goats and poultry & $\begin{array}{l}\text { Goats on a semi - } \\
\text { intensive basis while } \\
\text { poultry on intensive } \\
\text { basis }\end{array}$ & $\begin{array}{l}\text { Goats excreta is collected in } \\
\text { solid form on an irregular } \\
\text { bases and disposed of at a } \\
\text { nearby dump site; poultry } \\
\text { manure is collected together } \\
\text { with litter on a batch by batch } \\
\text { basis. }\end{array}$ \\
\hline LKH4 & $\begin{array}{l}\text { Kaduna polytechnic } \\
\text { Quarters along Kachia } \\
\text { Road, Kaduna South LGA }\end{array}$ & $\begin{array}{l}\text { Supplementary source } \\
\text { of water for animal } \\
\text { feeding only }\end{array}$ & Goats and poultry & $\begin{array}{l}\text { intensive housing } \\
\text { system }\end{array}$ & $\begin{array}{l}\text { Animal wastes are collected in } \\
\text { solid form, tied in bags and } \\
\text { sold at low prices to arable } \\
\text { crop farmers. Unsold manure } \\
\text { is disposed of by dumping at } \\
\text { the waste dump site along } \\
\text { Kachia Road express way. }\end{array}$ \\
\hline LKH5 & $\begin{array}{l}\text { Kaduna polytechnic } \\
\text { Quarters along Kachia } \\
\text { Road, Kaduna South LGA }\end{array}$ & $\begin{array}{l}\text { Supplementary source } \\
\text { of water for animal } \\
\text { feeding only }\end{array}$ & Poultry only & $\begin{array}{l}\text { intensive housing } \\
\text { system }\end{array}$ & $\begin{array}{l}\text { Birds excreta are swept } \\
\text { regularly together with feed } \\
\text { remnants and tied in bags and } \\
\text { sold at low prices to arable } \\
\text { crop farmers. Unsold manure } \\
\text { is disposed of by dumping at } \\
\text { the waste dump site along } \\
\text { Kachia Road express way. }\end{array}$ \\
\hline LKH6 & $\begin{array}{l}\text { Mando Road, Kaduna } \\
\text { North LGA }\end{array}$ & $\begin{array}{l}\text { Supplementary source } \\
\text { of water for animal } \\
\text { feeding only }\end{array}$ & Goats and sheep & open lot system & $\begin{array}{l}\text { Animal dung are swept and } \\
\text { kept in heaps and sold at low } \\
\text { prices to arable crop farmers. } \\
\text { The unsold manure remains } \\
\text { heaped until a buyer is found } \\
\text { for it. }\end{array}$ \\
\hline LKH7 & $\begin{array}{l}1 \mathrm{~km} \text { from LKH6 along } \\
\text { Mando Road, Kaduna } \\
\text { North LGA }\end{array}$ & $\begin{array}{l}\text { basic source of water } \\
\text { for both human and } \\
\text { animal consumption }\end{array}$ & Goats & $\begin{array}{l}\text { semi intensive housing } \\
\text { system }\end{array}$ & $\begin{array}{l}\text { The pen is cleaned irregularly } \\
\text { to collect animal manure in } \\
\text { solid form. The manure is } \\
\text { disposed of at a waste } \\
\text { dumpsite nearby that is used } \\
\text { by the community. }\end{array}$ \\
\hline LKH8 & Behind Kawo Abattoir & $\begin{array}{l}\text { Supplementary source } \\
\text { of water for animal } \\
\text { feeding only }\end{array}$ & poultry & intensive basis & $\begin{array}{l}\text { Poultry waste is disposed of } \\
\text { together with the litter through } \\
\text { the Kaduna state } \\
\text { environmental sanitation } \\
\text { agencies' disposal trucks, after } \\
\text { each batch of broilers. }\end{array}$ \\
\hline
\end{tabular}

